\title{
P3103
}

\section{車両組立工場における睡眠時呼吸障害事例の検討 一付属病院との医療連携を含めた包括的対応についてー}

\author{
石川 貴之、岩田 全充 \\ トヨ夕自動車株式会社 メディカルサポート部 産業医学グループ
}

【背景と目的】睡眠時呼吸障害（SDB：sleep-disordered breathing)、とくに睡眠時無呼吸症候群 (SAS : sleep apnea syndrome) は、昼間傾眠によ る産業事故のリスクや、低酸素血症による心血管 系疾患のリスクの増大などをもたらし、産業衛生 の分野においても重要な課題である。本研究では、 トヨ夕の某車両組立工場に扔ける睡眠時呼吸障害 の実態について報告する。【対象と方法】2005 年 1 月から 11 月までに健康診断の問診で「睡眠中呼吸 が停止 (10 秒以上)すると言わ机たことがある」と 申告した者のうち、病院受診をした者は 33 例であ り、このうち診断が確定した 26 例 (当該期間の健 診受診者の $0.8 \%$ ）につき、肥満度、昼間傾眠の申 告、治療適応の有無等について調査した。さらに、 この中で付属病院を受診し診断ならびに治療がな された 21 例につき、睡眠時呼吸障害の臨床指標と しての、Epworth Sleepiness score (ESS)、無呼 吸指数 $(\mathrm{AHI})$ 等を調查した。臨床指標については 治療が行なわれたものについては治療前後の比較 も行なった。さらに、就業制限付与状況についても 検討した。【結果】病院受診の結果、SAS と診断さ れ、CPAP、口腔内装具 $(O A)$ 、扁桃摘出等の治療 の適応と判断されたものは 26 例中 11 例 $(42 \%)$ で、残り 15 例は治療対象外と診断された。治療適 応群と治療対象外群において、BMI の平均はそれ ぞれ $26.7 \pm 2.8$ と $24.3 \pm 2.9$ で、治療適応群で有意に 高值であり $(\mathrm{p}<0.05)$ 、治療適応群のうち健診の段 階で「昼間傾眠あり」との申告があったものは約半 数の 5 例であった。また、付属病院で診断をうけた 21 例に扔いて、治療適応群 8 例と治療対象外群 13 例の ESS の平均は、それぞれ $6.5 \pm 3.3$ と $8.7 \pm 4.8$
であった。すでに治療中の 8 例のうち 7 例が $\mathrm{OA}$ 、 1 例が CPAPで治療を受けており、詳細な治療経 過が判明している 4 例は、いずれも $\mathrm{OA}$ よる治療 を受け、治療前後氾㧍ける AHI はそれぞれ 52.8 か ら 2.0、39.7 から 0.7、13.2 から 2.5、14.8 から 7.9 と 改善がみられた。就業制限については、治療適応群 のうち 3 例に対して運転ならび高所作業の制限 を付与しているが、これらはすべて治療待ちの者 であり、治療が定着した 8 例には特に制限を付与 していない。【考察】当社ではSAS に対し、各事業 所での健診時の問診による拾い上げ、付属病院で のアプノモニターならびに polysomnography (PSG) に上る診断、CPAPやOA による治療、診 断治療結果の各事業所へのフィードバックによる 就業配慮という流れで対応を行なっている。治療 適応になったもので、健診時に昼間傾眠の申告の あったものは約半数であり、ESS と SAS の重症度 も相関しないことから、昼間傾眠の申告がないこ とを理由に SAS の検查対象から除外すべきでは ないと考光られる。今後は、自己申告の次よらな い、肥満者、高血圧の従業員などへの SAS のスク リーニング検查や眠気の客観的評価の導入を考慮 することも必要であろう。また、車両組立工場では 運転作業化つてもトラックの長距離運転よりも リフトなどの構内運転が主体であり、治療が定着 すれば就業制限は必要ないと考元られるため、事 故や合併症防止の観点でも睡眠時無呼吸や昼間傾 眠について正しく申告し治療を受けてもらうこと の啓蒙も必要である。今後さらに事例を追加し報 告の予定である。 